would thus appear that three generic appellations have been given to this curious genus, that of Professor Stimpson having the precedence. Naturalists are indebted, however, to M. Lacaze-Duthiers for the detailed account he has now given of its structure.

\title{
On the Extension of certain marine Fishes to the freshwater Rivers of India.
}

\section{To the Editors of the Annals and Magazine of Natural History.}

Gentlemen.-Dr. Günther, in reply to my note impugning his statement regarding the extension of certain genera of marine fishes to Nepal, states that he has received information that several species of Therapon are exclusively inhabitants of fresh water. Now, without denying this statement, I must say that it is quite opposed to my own experience. No doubt some species of Therapon frequent streams of fresh water near the sea, as well as tidal rivers and backwaters, as I many years ago pointed out, stating that I had caught one species of Therapon, with fly, in small streams on the Malabar coast; but I doubt if any species extends, in non-tidal rivers, more than a very few miles from the sea.

2. This, however it may be, does not affect my refutation of its extension to Nepal, which I emphatically deny, as well as that of the other marine genera of fishes mentioned by Günther as extending to Nepal. I have not his paper at hand, but, writing from memory, aided by a Catalogue of Hodgson's collections, I believe that, besides Therapon and Scatophagus, he makes a Serranus, two Diagramma, Sillago, and Trachinotus all extend to the rivers of Nepal, which, I need hardly again say, is perfectly erroneous. The only marine genera that I know which extend beyond the influence of the tides in India are Coroina, Mugil, and one or two Clupeoid fishes, including the celebrated Hilsa fish (Alosa ilisha), which, however, does not extend nearly so far as the mountain-streams of Nepal.

3. With regard to Dr. Günther's rejection of my generic name Pristolepis, because he was unable to recognize it, I can only state that a much less experienced ichthyologist, Dr. Day, in a copy of his ' Fishes of Cochin,' quite recently received by me, though forwarded last July, gives a footnote to Catopra malabarica (in manuscript), in which he states that in his large work with illustrations he shall give it as his opinion that Pristolepis must be preferred to Catopra.

4. The assumption by any one individual, however learned, to reject a genus or species because he states that he himself finds it impossible to recognize it, is certainly not authorized in the rules regarding nomenclature laid down in the Proceedings of the British Association.

I am, Gentlemen,

Yours obediently,

T. C. JERDON,

Camp, Muzuffurnuggur, Surgeon-Major. December 6, 1865 . 


\section{$2 \mathrm{BHL}$ Biodiversity Heritage Library}

1866. "On the extension of certain marine fishes to the freshwater rivers of India." The Annals and magazine of natural history; zoology, botany, and geology 17, 153-153.

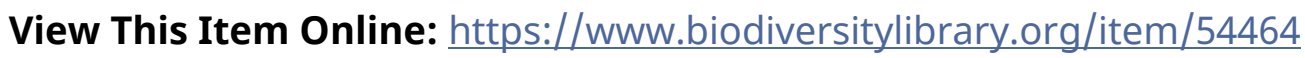

Permalink: https://www.biodiversitylibrary.org/partpdf/53709

\section{Holding Institution}

Smithsonian Libraries

\section{Sponsored by}

Smithsonian

\section{Copyright \& Reuse}

Copyright Status: Public domain. The BHL considers that this work is no longer under copyright protection.

This document was created from content at the Biodiversity Heritage Library, the world's largest open access digital library for biodiversity literature and archives. Visit BHL at https://www.biodiversitylibrary.org. 